\title{
An Overview of Boko Haram Insurgency in Nigeria
}

\author{
Adam Adem Anyebe
}

\author{
Department of Public Administration, Faculty of Administration, Ahmadu Bello University, Zaria- Nigeria
}

\author{
*Corresponding Author: \\ Adam Adem Anyebe \\ Email: adamanyebe@gmail.com
}

\begin{abstract}
This study attempted to carry out an overview of the Yussufiyya Boko Haram sect and its activities in Nigeria. Secondary data obtained mainly from National newspapers and the internets were used in the analysis. It was revealed that the sect emerged mainly as a reaction to western value system which was believed to have polluted our culture. Boko Haram which was once a social communal movement gradually metamorphosed into a vicious sect operating in some states of the north-east of Nigeria. The study also showed that Boko Haram had a dream of establishing a kind of Utopian egalitarian society and to achieve this task, recruited gullible youths to stage a Jihad in an attempt to Islamize, at least the northern part of Nigeria. The sect in recent past has evolved and proliferated to such a frightening point that it could engage the Nigerian military in full-blown confrontation in an attempt to pursue its ruthless expansionist ambition. This ambition has however, been significantly checked as the sect has been technically defeated and restricted to the sambisa forest. It is recommended among others that government should continue to use the carrot and stick approach in handling the insurgency while making attempts to have an understanding of the sect's ideology as this will assist in the deradicalisation process.
\end{abstract}

Keywords: Boko Haram, Attack, Jihad, Islam, Destruction

\section{INTRODUCTION}

The Boko Haram, sometimes referred to as Yussufiyya Boko Haram (named after its founding leader, Mohammed Yusuf) is a complex phenomenon which poses a great threat to national security and socio-economic life in Nigeria. The different issues and interests that are factored into Boko Haram does not make it amenable to a unilinear perspective. In essence, it is a many sided process, which needs to be holistically examined for comprehensive understanding. This insurgency which is often perceived as a frantic effort to oppose the status quo by inducing fear in civilian population and in the state through widespread and publicised use of violence became a frequent occurrence in the country in the recent past.

More often than not, the main motive of the group as believed by many is usually to protest and fight perceived injustices of the existing economic and political order through acts of violence. The sect which was initially an Islamic movement against the corrupting influence of western education has become politicized given its links to frustrated politicians, who are themselves products of western education. The ideology and philosophy of the sect have therefore, become terribly nuanced as it continues to oscillate between politics and religion. Initially, the sect propounded the doctrine of hating everything "western" in the Nigerian society. In other words, western education and its influences are evil. According to Odey
[1], Boko Haram sect tells us that western education and the entire gamut of western influence is $\sin . . . .$. they are not pleased with the secular status of Nigeria; they want Nigeria to become a religious state where the tenets of Islam, particularly the Shari'a law, would reign supreme. However, the deliberate and rabid destruction of every available institutional structure, killing and maiming of innocent human beings, both Christians and Muslims, and the grounding of any useful infrastructure in different parts of the country raise the enigma of what their aim really is.

Boko Haram started as a group made up of perceived socially excluded, deprived and unemployed set of Islamic seminary students of late Mohammed Yusuf. The sect withdrew from the larger society in 1992 and established a camp in Kannamma Village of Yobe State and tagged themselves ahalulsunnahwaljamahijirah and/or the Nigerian 'Taliban' and launched several attacks on divisional police stations in January 1994 [2].

'Yusufiyya' later metamorphosed and embraced the most extreme and advanced teachings from hijirah to Jama'atul Ahalul Sunna Waljama'a Lidda a' wati Wal Jihadi (JASWAL JIHAD) with significant number of members resigning themselves to fate and willing to die in planned attacks. Blum as cited by Bintube [2] described the nature of suicide bombings by the Boko Haram as involuntarily administered 
suicide Furthermore, in recent times, Boko Haram has been variously described as a hydra-headed monster that inflicts pain, with every attack, on the structure of the Nigerian society in what Blum as cited by Bintube [2] in his assessment of the periodic bombing, referred to as colossal collateral damage.

Nigerians have witnessed, almost helplessly, the reckless destruction of human lives and properties, especially in the northern states of Borno, Yobe, Adamawa, amongst others, where Islam is the dominant religion. In fact Boko Haram's attempts to barbarize and terrorize Nigeria and Nigerians have grown, largely unchecked, and many observers fear that the most populous black nation on earth may be wiped out of existence because of the massiveness of the daily security threats in the recent past, though drastically reduced by the Buhari administration. It took Jonathan administration up to about three years to have any reasonable reading of the Boko Haram situation. Igbonovia \& Edobor-Igbonovia [3] argue that in the Nigerian national context, words do not match action as reflected in the lamentations:

It appears that the government of the day has given up on the insecurity in the country. For some months now, hardly a day passes without an accident of bombing or shooting taking place in Nigeria. In all of this, lives are usually lost and valuable properties destroyed.... The Federal Government....does not appear to have an answer to the security challenges. Government has been running from pillar to post, striving to deal with the issues. But rather than make any head way, the menacecontinue to rear its ugly head.

It is against this background that this research poses this question: What is the extent and the current status of the Boko Haram insurgency in Nigeria?

\section{Method of Data Collection}

The data used in this study were obtained mainly from the following sources:

i. Daily Trust, June 18, 2016

ii. Weekly Trust

iii. Nigerian Tribune (August 26, 2011; December 28, 2011; December 30, 2011; January 28, 2012, April 29, 2012 and June 25, 2012)

iv. Daily Sun, March 31, 2016. Available online at www.sunnewsonline.com

v. The Guardian Newspaper, April 26, 2014

vi. The Punch Newspaper, April 13, 2014

vii. New Express, March 30, 2014

viii. Internet materials

\section{RESULTS AND DISCUSSION}

The emergence of Boko Haram insurgency in Nigeria has not only affected the strategic calculation of internal security in the country but has also completely altered the shape of the domestic security equation. Apart from the threat to security, the sect has reconfigured the theme of the age-long strategic notion of security through state-centric grandiose military preparedness [4].

The Boko Haram, hitherto a relatively simple and mechanical group of socially excluded Islamic seminary students graduated to a violent, destructive, complex and organic one capable of confronting the Nigerian military. The sectis also labelled an 'instrument of political re-engineering' being used by unscrupulous political elements to stage a proxy war in their quest for political power, thereby threatening government, institutions and targeted civilian populations in their insurgency to achieve their political end. The fact that Boko Haram emerged from a collapsed Borno Empire there is the notion that Yusuffiya Boko Haram is viewed as an instrument for resurrecting a dead empire. Others see the Boko Haram as 'freedom fighters' from the perspective of their frequent prison breaks and freeing of inmates. This view supported the work of some writers who observed that injustice, inequality and dehumanisation bred the crisis of Yusuffiya Boko Haram insurgency which Nigeria is facing today.

In line with Wicker's thoughts as cited by Bintube [2], Boko Haram insurgence was created out of perceived injustices of our time, and of a state that has no compunction about 'murdering' people in the name of justice. The celebrated cases of the dehumanising extrajudicial killings of the Boko Haram leader and members in Nigeria between Wednesday $29^{\text {th }}$ and $30^{\text {th }}$ of July 2009 are classical cases that resulted in Boko Haram revolts and expansions and leading to what Blum referred to as 'colossal collateral damage' to the society.

\section{Selected Activities of Boko Haram in Nigeria}

The ruthlessness and massiveness of the destruction of human lives and properties in different parts of the country unquestionably put Boko Haram attacks as pogroms which every right thinking person must condemn and denounce. A selected cases of Boko Haram ruthless attacks reveals the gargantuan proportions of the destruction the sect has wrought: 
Table 1: Selected cases of Boko Haram attacks since 2009

\begin{tabular}{|c|c|c|c|}
\hline S/No & Date & Location & Principal Actor \\
\hline 1 & $\begin{array}{l}\text { July26 and 29, } \\
2009\end{array}$ & $\begin{array}{l}\text { Yobe, Bauchi, } \\
\text { Adamawa, Kano } \\
\text { and Kaduna in } \\
\text { the north-west as } \\
\text { well as the } \\
\text { Federal Capital, } \\
\text { Abuja }\end{array}$ & $\begin{array}{l}\text { The attacks were not limited to Borno State alone but spread to } \\
\text { other states in the north-east such as Yobe, Bauchi, Adamawa, } \\
\text { Kano and Kaduna in the north-west. The Federal Capital, Abuja, } \\
\text { was not left out in the wanton destruction of lives and } \\
\text { properties.Boko Haram also bombed Louis Edet House, } \\
\text { headquarters of the Nigeria Police on Thursday June 16, 2011, and } \\
\text { this was followed on Friday, August } 26,2011 \text { with the bombing of } \\
\text { the United Nations (UN) House by suicide bombers. Between } 26 \\
\text { and } 29 \text { July, 2009, the Yusuffiya Boko Haram insurgents had free } \\
\text { reign in the capital city of Maiduguri, Borno State, killing or } \\
\text { maiming innocent citizens in their battle with law enforcement } \\
\text { agents, even claiming most parts of the city as theirs, until the } \\
\text { federal government sent the military to the city on July } 29,2009 \text { to } \\
\text { recapture areas that were hitherto under their control. }\end{array}$ \\
\hline 2 & August 26, 2011 & Abuja & $\begin{array}{l}\text { Abuja. Boko Haram suicide bomber in a car drove straight into the } \\
\text { UN building; Boko Haram raided a bank in Misau, Bauchi State, } \\
\text { killing } 5 \text { policemen, robbing the bank, killing } 4 \text { soldiers a day after, } \\
\text { different parts of Borno and Yobe States came under attacks by the } \\
\text { sect in November, 2011. In the attacks a number of Yobe State } \\
\text { buildings were massively destroyed at least } 67 \text { persons were killed. }\end{array}$ \\
\hline 3 & $\begin{array}{l}\text { December 28, } \\
2011\end{array}$ & Damaturu & $\begin{array}{l}\text { Nigerian Tribune reported some terrorist attacks unleashed by } \\
\text { Boko Haram, captioned "Chronicles of Boko Haram Attacks". } \\
\text { They are: November 4: Sect members bombed government } \\
\text { buildings and shut their ways through the city of Damaturu, killing } \\
\text { more than } 100 \text { people, while bombing and a suicide attack at } \\
\text { Maiduguri left } 4 \text { dead. August } 26 \text { : A Sect member detonated a car } \\
\text { loaded with explosives at the United Nations Headquarters in } \\
\text { Nigeria's capital Abuja, killing } 24 \text { people and wounding another } \\
\text { 116. April 16: A car loaded with explosives got detonated at the } \\
\text { Federal police headquarters in Abuja, killing at least two people. } \\
\text { The police first called the attacks as suicide bombing, but later } \\
\text { denied it. April 9: Gunmen with the sect set fire on the Maiduguri } \\
\text { International Hotel and killed a politician ahead of local elections. } \\
\text { December } 31 \text {, 2010: A bomb allegedly planted by the sect } \\
\text { exploded at a crowded and popular outdoor beer garden at a } \\
\text { military barracks in Abuja, killing at least } 4 \text { people. September } 7 \text {, } \\
\text { 2010. The sect freed about } 700 \text { inmates from Bauchi Federal } \\
\text { Prison. July 2009: About } 700 \text { people died after sect members rioted } \\
\text { and a security crackdown hit Maiduguri, the sect's spiritual home. }\end{array}$ \\
\hline 4 & $\begin{array}{l}\text { December } \\
2011\end{array}$ & $\begin{array}{l}\text { Suleja, } \\
\text { State }\end{array}$ & $\begin{array}{l}\text { President Goodluck Jonathan addressed the nation on security } \\
\text { issues that made } 2011 \text { tick. Striking excerpts are as follows: Suleja } \\
\text { INEC in Niger State was bombed on April } 8,2011 \text {, leaving } 16 \\
\text { people dead mainly members of the NYSC; gunmen shooting in } \\
\text { Damaturu, Yobe State, killing more than } 100 \text { persons,.... One } \\
\text { another occasion December } 22-24 \text { at Damaturu, Boko Haram } \\
\text { terrorists killed } 61 \text { persons. A Nigerian Tribune reported that Boko } \\
\text { Haram member detonated a car loaded with explosives at the } \\
\text { United Nations Headquarters in Abuja, } 24 \text { casualties, comprising } \\
\text { Nigerians and foreign staff of the UN was recorded with about } 116 \\
\text { wounded. }\end{array}$ \\
\hline 5 & $\begin{array}{l}\text { December } \\
2011\end{array}$ & Kano & $\begin{array}{l}\text { Nigerian Tribune, back page: "The bomb wiped out whole families } \\
\text { and scalped a baby.....dozen of worshippers suffered shocking } \\
\text { injuries that may lead to permanent disability. Boko Haram, due to } \\
\text { its activities is said to have displaced over } 90,000 \text { people in Yobe } \\
\text { State. }\end{array}$ \\
\hline 6 & $\begin{array}{l}\text { December } \\
2011\end{array}$ & Niger State & $\begin{array}{l}\text { Nigerian Tribune reported suicide attack on the St. Theresa } \\
\text { Catholic Church, Madalla. The Christmas Day attack by Boko }\end{array}$ \\
\hline
\end{tabular}




\begin{tabular}{|c|c|c|c|}
\hline & & & $\begin{array}{l}\text { Haram bomb blast left } 7 \text { vehicles burnt, } 4 \text { churches destroyed, } 35 \\
\text { people dead and more than } 80 \text { people wounded. }\end{array}$ \\
\hline 7 & $\begin{array}{l}\text { December } 30 \text {, } \\
2011\end{array}$ & Delta State & $\begin{array}{l}\text { Nigerian Tribune reported that Sapele L.G.A of Delta State, } 9 \\
\text { children and a woman in the bomb explosion by Boko Haram that } \\
\text { rocked an Islamic School }\end{array}$ \\
\hline 8 & $\begin{array}{l}\text { December 30, } \\
2011\end{array}$ & Gombe State & $\begin{array}{l}\text { Nigerian Tribune reported that Gombe, } 15 \text { people injured in a } \\
\text { bomb blast explosion by Boko Haram in a hotel. } \\
\text { Nigerian Tribune, January 28, 2012, also reported; "For months, } \\
\text { the nation has been battling the series of attacks and bomb } \\
\text { explosions perpetrated by members of the terrorist group in the } \\
\text { Northern part of the country which had led to the death of innocent } \\
\text { Nigerians in their hundreds ... speculations became rife that the } \\
\text { dreaded Boko Haram had stormed Bayelsa with bombs and other } \\
\text { explosives to unleash violence on Mr. President's home state. }\end{array}$ \\
\hline 9 & June 25,2012 & Yobe State & $\begin{array}{l}\text { Nigerian Tribune reported that the Boko Haram attacked the prison } \\
\text { through the emir's palace, } 40 \text { inmates escaped. They attacked with } \\
\text { rifles. }\end{array}$ \\
\hline 10 & April 29, 2012: & Kano State & $\begin{array}{l}\text { Nigerian Tribune reported that Ado Bayero University, Kano was } \\
\text { attacked by gunmen suspected to be Boko Haram members killing } \\
\text { church worshippers. }\end{array}$ \\
\hline 11 & January 28, 2012 & Kano State & $\begin{array}{l}\text { Nigerian Tribune reported that the day Kano turned theatre of } \\
\text { war... Last Friday } 20 / 11 / 2012 \text {, will not be forgotten in a hurry by } \\
\text { the people of ancient city of Kano ... both Muslims and Christians } \\
\text { were running helter-skelter for their lives due to multiple bomb } \\
\text { blast explosions that rocked the city occasioned by the Boko } \\
\text { Haram, the dreaded Islamic sect... with several hundreds of } \\
\text { people dead and several wounded, several properties, both, private } \\
\text { and government worth millions of naira were destroyed ... } 29 \\
\text { policemen, } 3 \text { SSS officers, } 2 \text { immigration officers, } 1 \text { custom officer } \\
\text { and a total of } 150 \text { civilians including a journalist were killed by the } \\
\text { extremists during the massacre in the state... back to Kano Bompai } \\
\text { police barracks and unknown to many people (number not } \\
\text { specified) running away either from Dakata and its environs } \\
\text { enroute Club road and King's garden they all fell to the bullets of } \\
\text { the Boko Haram or those of security operatives who were there for } \\
\text { counter attacks. The extremists attacked and brutally killed } \\
\text { innocent civilians who were going about their lawful business } \\
\text { along Tundu Wada road. On the following Sunday, when President } \\
\text { Goodluck Jonathan visited Kano, the Emir of Kano, Alhaji Ado } \\
\text { Bayero could not control his emotion and wept while receiving Mr. } \\
\text { President'. On page } 14 \text { of the same newspaper, January } 28,2012 \text {, } \\
\text { journalists reported in addition, that the recent bomb attack by } \\
\text { Boko Haram sect on Kano has made it one attack too many... the } \\
\text { bombing attacks on lives and properties have left the society } \\
\text { devastated and people living in fear, the once sonorous sound of } \\
\text { music in these homes has turned into a dirge. Nothing seems to } \\
\text { comfort the chief mourners who were yet to wake up to that reality } \\
\text { that their loved ones were gone. Their bread winners, best friends } \\
\text { were gone without bidding the farewell. }\end{array}$ \\
\hline 12 & $\begin{array}{l}\text { October } 29, \\
2012: \\
\text { Independent } \\
\text { Radio News } \\
\text { Benin at } 6.00 \mathrm{am}\end{array}$ & Benin City & $\begin{array}{l}\text { Independent Radio News Benin at } 6.00 \text { am reported that gunmen } \\
\text { and suicide bombers attacked St. Rita's Catholic Church at Kaduna } \\
\text { killing } 5 \text { people and leaving } 98 \text { seriously wounded. }\end{array}$ \\
\hline 13 & $\begin{array}{l}\text { February 22, } \\
2013\end{array}$ & Yobe State & $\begin{array}{l}\text { Some corps members gruesomely burnt by Boko Haram in Yobe } \\
\text { State (www.Nairaland.com/712404/bokoharam) }\end{array}$ \\
\hline 14 & May 9, 2013 & $\begin{array}{l}\text { Baga, } \quad \text { Borno } \\
\text { State }\end{array}$ & $\begin{array}{l}\text { Boko Haram attacked and destroyed Bama Battalion Barracks; } \\
\text { killed } 6 \text { police, } 14 \text { Prison staff, } 2 \text { soldiers, } 4 \text { civilians while } 21 \text { Boko } \\
\text { Haram members died in the clash. Similarly, on April } 16 \text { and } 17\end{array}$ \\
\hline
\end{tabular}




\begin{tabular}{|c|c|c|c|}
\hline & & & $\begin{array}{l}\text { 2013, the Boko Haram members engaged in another clash with the } \\
\text { multinational joint task force (MJTF) in Baga Local Government } \\
\text { Area of Borno State in which } 185 \text { people died and thousands of } \\
\text { houses were burned. In responses to these colossal collateral } \\
\text { damages and massacre on the structure of the society, the President } \\
\text { and Commander-in-Chief of the Armed Forces of the Federal } \\
\text { Republic of Nigeria, Goodluck Ebele Jonathan, on Tuesday, May } \\
14,2013 \text { declared a state of emergency in the three most highly } \\
\text { affected states of the North-East; Borno, Yobe and Adamawa } \\
\text { States (The Nation, 2012). }\end{array}$ \\
\hline 15 & February8, 2013 & Kano State & $\begin{array}{l}\text { The Guardian newspaper reported that } 10 \text { female health workers } \\
\text { were killed, unsuspected gunmen later claimed to be Boko Haram } \\
\text { sect in Kano State claimed responsibility. } \\
\text { (www.guardiannewspaperonline) }\end{array}$ \\
\hline 16 & May 15,2013 & $\begin{array}{l}\text { Borno, Yobe and } \\
\text { Adamawa States }\end{array}$ & $\begin{array}{l}\text { Nigerian troops begin an offensive attack against Boko Haram in } \\
\text { the states of Borno, Yobeand Adamawa, where a state of } \\
\text { emergency was declared in order to retake areas which had fallen } \\
\text { into the hands of insurgents. (http://news.naij.com/60318.html) }\end{array}$ \\
\hline 17 & June 4, 2013 & & $\begin{array}{l}\text { Nigeria formally declared Boko Haram and Ansaru, its suspected } \\
\text { offshoot, "terrorist" groups and issued a law to ban } \\
\text { them.(http://news.naij.com?60318.html) }\end{array}$ \\
\hline 18 & July 6, 2013 & Yobe State & $\begin{array}{l}\text { Gunmen believed to be from Boko Haram attacked a secondary } \\
\text { school in the north-eastern state of Yobe, killing } 42 \text { people, many } \\
\text { of whom were students. (http://news.naij.com/60318.html) }\end{array}$ \\
\hline 19 & $\begin{array}{l}\text { August 10-11, } \\
2013\end{array}$ & $\begin{array}{l}\text { Konduga, Borno } \\
\text { State }\end{array}$ & $\begin{array}{l}\text { Suspected Islamic extremists killed } 56 \text { people in the north-west, } \\
\text { including } 44 \text { in an attack on a mosque in Konduga. } \\
\text { (http://news.naij.com/60318.html) }\end{array}$ \\
\hline 20 & $\begin{array}{l}\text { September12, } \\
2013\end{array}$ & Borno State & $\begin{array}{l}\text { A military strike on a highly-fortified Boko Haram camp in the } \\
\text { north-eastern state of Borno killed } 150 \text { Islamists. } \\
\text { (http://news.naij.com/60318.html) }\end{array}$ \\
\hline 21 & $\begin{array}{l}\text { September } 17, \\
2013\end{array}$ & Borno State & $\begin{array}{l}\text { An attack by Boko Haram extremists disguised in military } \\
\text { uniforms in the north-eastern Benisheik area in Borno State with at } \\
\text { least } 142 \text { killed. (http://news.naij.com/60318.html) }\end{array}$ \\
\hline 22 & $\begin{array}{l}\text { September 29, } \\
2013\end{array}$ & Yobe State & $\begin{array}{l}\text { Boko Haram gunmen opened fire on sleeping students in a collage } \\
\text { dormitory in north-eastern Yobe State, killing at least } 40 \text { people. } \\
\text { (http://news.naij.com/60318.html) }\end{array}$ \\
\hline 23 & $\begin{array}{l}\text { November 13, } \\
2013\end{array}$ & & $\begin{array}{l}\text { The United States blacklisted Boko Haram and Ansaruas terror } \\
\text { groups. (http://news.naij.com/60318.html) }\end{array}$ \\
\hline 24 & $\begin{array}{l}\text { December 2, } \\
2013\end{array}$ & $\begin{array}{l}\text { Maiduguri, } \\
\text { Borno State }\end{array}$ & $\begin{array}{l}\text { Hundreds of heavily armed Boko Haram gunmen besieged an air } \\
\text { force and army base in the north-eastern city of Maiduguri, } \\
\text { destroying an aircraft, razing buildings and setting shops and petrol } \\
\text { stations ablaze. (http://news.naij.com/60318.html) }\end{array}$ \\
\hline 25 & $\begin{array}{l}\text { December 16, } \\
2013\end{array}$ & & $\begin{array}{l}\text { The United Nations said attacks by Boko Haram had killed more } \\
\text { than } 1,200 \text { people since May. (http://news.naij.com/60318.html) }\end{array}$ \\
\hline 26 & $\begin{array}{l}\text { December 20, } \\
2013\end{array}$ & $\begin{array}{l}\text { Bama,Borno } \\
\text { State }\end{array}$ & $\begin{array}{l}\text { Scores of suspected Islamic gunmen stormed a military barrack in } \\
\text { the north-eastern town of Bama, spraying gunfire at the troops } \\
\text { inside before torching the } \\
\text { (http://news.naij.com/60318.html) }\end{array}$ \\
\hline 27 & January 26, 2014 & Borno State & $\begin{array}{l}\text { At least } 78 \text { people were killed in two separate attacks in north-east } \\
\text { Nigeria, on a busy market in Borno State and the other in } \\
\text { neighbouring Adamawa, with suspicions falling on Boko Haram. } \\
\text { (http://news.naij.com/60318.html) }\end{array}$ \\
\hline 28 & $\begin{array}{l}\text { February } \\
2014\end{array}$ & Borno State & $\begin{array}{l}\text { An attack blamed on the sect left } 106 \text { dead in the mostly Christian } \\
\text { village of Izghe in Borno. (http://news.naij.com/60318.html) }\end{array}$ \\
\hline 29 & $\begin{array}{l}\text { February } \\
2014\end{array}$ & $\begin{array}{l}\text { Bama, } \\
\text { State }\end{array}$ & $\begin{array}{l}\text { An attack by scores of Boko Haram Islamist in the north-east town } \\
\text { of Bamaleft } 60 \text { people dead and caused major damage to public } \\
\text { buildings. (http://news.naij.com/60318.html) }\end{array}$ \\
\hline 30 & $\begin{array}{l}\text { February } \\
2014\end{array}$ & $\begin{array}{l}\text { Southern } \\
\text { Regions }\end{array}$ & 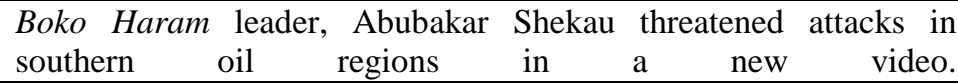 \\
\hline
\end{tabular}


Adam Adem Anyebe.; Saudi J. Humanities Soc. Sci.; Vol-1, Iss-2(Apr-Jun, 2016):55-61

\begin{tabular}{|c|c|c|c|}
\hline & & & (http://news.naij.com/60318.html) \\
\hline 31 & $\begin{array}{l}\text { February 25, } \\
2014\end{array}$ & $\begin{array}{l}\text { BuniYadi, Yobe } \\
\text { State }\end{array}$ & $\begin{array}{l}\text { Suspected Boko Haram insurgents killed } 43 \text { people when they } \\
\text { attacked sleeping secondary school students in the town of } \\
\text { BuniYadi in Yobe State. (http://news.naij.com/60318.html) }\end{array}$ \\
\hline 32 & March 30,2014 & & $\begin{array}{l}\text { No fewer than } 30 \text { persons were killed that morning when Boko } \\
\text { Haram attempted to seize the national headquarters of the } \\
\text { Department of State Security (SSS). Following the attempted } \\
\text { jailbreak of detained Boko Haram members in the rumor mills, the } \\
\text { presidential spokesperson had to reassure Nigerians that the } \\
\text { president, Dr. Goodluck Ebele Jonathan is safe. (News Express, } \\
\text { March 30, 2014) }\end{array}$ \\
\hline 33 & April 13, 2014 & $\begin{array}{l}\text { Gwoza rand } \\
\text { Konduga, Borno } \\
\text { State }\end{array}$ & $\begin{array}{l}\text { The Punch Newspaper reported that men believed to be members } \\
\text { of the Boko Haram sect had again invaded Borno villages of } \\
\text { Nagoshe and Kaigamari, in Gwoza and Konduga local government } \\
\text { areas respectively, } \quad \text { killing } \\
\text { (www.punchnewspaperonline.com) }\end{array}$ \\
\hline 34 & April 14, 2014 & Nyanya, Abuja & $\begin{array}{l}\text { Nigerian Televison Authority News Abuja at 9:00 pm reported that } \\
\text { scores of people were killed and maimed as an early morning bomb } \\
\text { explosion rocked a motor park in Nyanya area of Federal Capital } \\
\text { Territory, Abuja. }\end{array}$ \\
\hline 35 & April 16, 2014 & $\begin{array}{l}\text { Chibok, Borno } \\
\text { State. }\end{array}$ & $\begin{array}{l}\text { The GuardianNewspaper reported that Boko Haram abducted } 219 \\
\text { female students from a secondary school in Chibok, Borno State. }\end{array}$ \\
\hline 36 & June 13, 2016 & $\begin{array}{l}\text { Askira, } \quad \text { Borno } \\
\text { State }\end{array}$ & $\begin{array}{l}\text { Top Boko Haram recruiter arrested and he confessed how he } \\
\text { enlisted three of his sons. The military confirmed that many Boko } \\
\text { Haram terrorists were trapped in Sambisa forest following } \\
\text { sustained offensive by soldiers. The theatre commander of } \\
\text { Operation Lafiya Dole, Maj-Gen. Lucky Irabo also said the } \\
\text { operation of the military troops had reduced the capacity of the } \\
\text { insurgents to fight. }\end{array}$ \\
\hline
\end{tabular}

Source: Largely adapted from Omoera et al [5] and Bintube [2]

The effect of this encounter with Boko Haram in terms of human casualty, properties, social values and the stigma experienced by people in Maiduguri were unspeakable. The number of human lives lost in Borno and other northern states cannot be accurately established, but suffice to say that many lost relatives and friends in the encounter. According to Daily Trust on Saturday, June 18, 2016, Boko Haram has created 49,000 orphans in Borno State [6].

The encounter ended with the capture of the MarkazIbn Taymiyya, the centre of the Boko Haram movement, and subsequent gruesome and extra-judicial killing of Muhammad Yusuf, whose death was to generate controversies at national and international levels, because security agents despite evidences of judicial murder of Yusuf kept giving contradictory statements. At a time the military operatives in Maiduguri confirmed that they had captured Yusuf alive and handed him over to the police, but to cover up the extra- judicial killing, the Police Command stated that Yusuf was killed during a shoot-out between the police and his armed followers. This action, according to Bintube [2] deprived the public of considerable information, as to his sponsors, network, and source of funds and weapons, if he had been put to trial. As a result, Yusuffiya Boko Haram became more daring, militant and deadly in their operations; their claim to have masterminded most of the bomb blasts across the country goes to show how deadly and daring it had become and a source of security concern for peace and development.

\section{CONCLUSION AND RECOMMENDATIONS}

The Boko Haram insurgency has engaged the attention of Nigerians and the Nigerian Government which has led to the establishment of a number of controls to try and curtail the excesses of the sect, ranging from declarations of state of emergency, deployment of the military, house-to-house raids, mounting of security check points at designated spots along major highways as well as seeking the cooperation of neighbouring countries. These controls, however, did not record any reasonable degree of success in the first three years as it was apparent that the ruthless attacks by the insurgents were on the increase. The ruthless activities of Boko Haram have touched every sphere of life. People have been displaced from their homes; families have lost loved ones and wives have become widows and children made fatherless and in some cases orphans. Furthermore, children have been denied education as their schools were constantly targeted and destroyed; police stations and the police have been rendered almost non-functional, and arms and ammunition catered away after most attacks; prisons have been attacked, bombed, and inmates set 
free. However, the Buhari administration has brought a ray of hope as the insurgents have been degraded and restricted to the sambisa forest with some sporadic attacks on soft targets.

It is therefore, recommended that the government should continue with the carrot and stick approach in handling the insurgency issue. Equally important is the economic empowerment scheme which the government has put in place to empower the growing population of jobless youths in the country. Finally and importantly too, attempts should be made to understand the phenomenon and the sect's strategic attacks and periodic bombings. It is crucial that the government make concerted efforts to understand the ideology of Boko Haram as well as the sources of their funds and weaponry.

\section{REFERENCES}

1. Odey, J. (2012). Boko Haram: Nigeria's path to disintergration. In S.O. Anyanwu \& I.U. Nwanaju (eds.) Boko Hara,: Religious Conflicts and Dialogue Initiatives in Nigeria 11. Enugu: Snaap Press Nigeria Ltd.

2. Bintube, M. (2015). Boko Haram Phenomenon: Genesis and Development in North Eastern Region Nigeria. International Journal of Sociologu and Anthropology Research, 1(1): 1-22.

3. Igbonivia, P. E., \& Igbonivia-Edobor, B. A. (2013). The national security advisor in the United States and Nigeria: A Comparative Perspective. The Constitution: A Journal of Constitutional Development, 13(1).

4. Otighile, A., \& Terkimbi, A. E. (2014). Rationalizing Boko Haram Insurgency in Nigeria: Contending Perspectives, in Governance, Peace and Security in Africa, I. Walter \& R. Momoh (eds). Nigeria AMBIK Press.

5. Omoera, O. S., \& Ogah, C. A. (2014). Boko Haram as an A-gent Pro-ca-teur of Destabilization and Destruction in Nigeria: The Media's Check , in Governance, Peace and Security in Africa, I. Walter \& R. Momoh (eds). Nigeria AMBIK Press.

6. Wakili, I. (2016). Boko Haram Created 49,000 Orphans in Borno State- Federal Government. Daily Trust, June 18, 2016. Available online at www.dailytrust.com.ng. 